\title{
Economic and Educational Aspects of Zoology.*
}

\author{
By Prof. J. Stanley Gardiner, M.A., F.R.S.
}

CREAT as have been the results in physical sciences applied to industry, the study of animal life can claim discoveries just as great. Their greatest value, however, lies, not in the production of wealth, but rather in their broad applicability to human life. Man is an animal, and he is subject to the same laws as are other animals. He learns by the experience of his forbears, but he learns also by the consideration of other animals in relationship to their fellows and to the world at large. The whole idea of evolution, for instance, is of indescribable value; it permeates all life to-day; and yet Charles Darwin, whose researches did more than any others to establish its facts, is too often known to the public only as "the man who said we came from monkeys."

Whilst, first and foremost, I would base my claim for the study of animal life on this consideration, we cannot neglect the help it has given to the physical welfare of man's body. It is not out of place to direct attention to the manner in which pure zoological science has worked hand-in-hand with the science of medicine. Harvey's experimental discovery of the circulation of the blood laid the foundation for that real knowledge of the working of the human body which is at the basis of medicine; our experience of the history of its development gives us good grounds to hope that the work that is now being carried out by numerous researchers under the term "experimental" will ultimately elevate the art of diagnosis into an exact science. Harvey's work, too, mostly on developing chicks, was the starting-point for our knowledge of human development and growth. Instances in medicine could be multiplied wherein clinical treatment has been rendered possible only by laborious research into the life-histories of certain parasites preving often on man and other animals alternately. In this connection there seems reason at present for the belief that the great problem of medical science, cancer, will reach its solution from the zoological side. A pure zoologist has shown that typical cancer of the stomach of the rat can be produced by a parasitic threadworm (allied to that found in pork, Trichina), this having as a carrying host the American cockroach, brought over to the large warehouses of Copenhagen in sacks of sugar. Our attack on such parasites is made effective only by what we know of them in lower forms, which we can deal with at will. Millions of the best of our race owe their lives to the labours of forgotten men of science who laid the foundations of our knowledge of the generations of insects and flat-worms, the modes of life of lice and ticks, the physiology of such lowly creatures as Amoba and Paramecium, and of parasitic diseasemalaria, Bilharziasis, typhus, trench fever, and dysentery.

Of immense economic importance in the whole domain of domestic animals and plants was the rediscovery early in the present century of the completely forgotten work of Gregor Mendel on cross-breeding, made known to the present generation largely by the labours of a former president of this Association, who, like a true man of science. claims no credit for himself. We see results already in the few years that have elapsed in special breeds of wheat, in which have been combined with exactitude the qualities man desires.

* From the opening address of the President of Section D (Zoology) delivered at the Cardiff meeting of the British Association on August 24 .

No. 2654 , VOL. IO6]
The results are in the making-and this is true of all things in biology-but can anyone doubt that the breeding of animals is becoming an exact science? We have got far, perhaps, but we want to get much further in our understanding of the laws governing human heredity; we have to establish immunity to disease. Without the purely scientific study of chromosomes (the bodies which carry the physical and mental characteristics of parents to children) we could have got nowhere, and to reach our goal we must know more of the various forces which in combination make up what we term life.

In agricultural sciences we are confronted with pests in half a dozen different groups of animals. We have often to discover which of two or more is the damaging form, and the difficulty is greater where the damage is due to association between plant and animal pests. Insects are, perhaps, the worst offenders, and our basal knowledge of them as living organisms-they can do no damage when dead, and perhaps pinned in our showcases-is due to Redi, Swammerdam, and to Réaumur in the middle of the eighteenth century. Our present successful honey production is founded on the curiosity of these men in respect to the origin of life and the generation of insects. The fact that most of the dominant insects have a worm (caterpillar or maggot) stage of growth, often of far longer duration than that of the insects, has made systematic descriptive work on the relation of worm and insect of peculiar importance. I hesitate, however, to refer to catalogues in which perhaps a million different forms of adults and young are described. Nowadays we know, to a large degree, with what pests we deal, and we are seeking remedies. We fumigate and we spray, spending millions of money, but the next remedy is in the use of freeliving enemies or parasities to prey on the insect pests. The close correlation of anatomy with function is of use here in that life-histories, whether parasitic, carni vorous, vegetarian, or saprophagous, can be foretold in fly-maggots from the structure of the front part of their gut (pharynx); we know whether any maggot is a pest, harmless, or beneficial.

I will not disappoint those who expect me to refer more deeply to science in respect to fisheries, but its operations in this field are less known to the public at large. The opening up of our north-western grounds and banks is due to the scientific curiosity of Wyville Thomson and his confrères as to the existence or non-existence of animal life in the deep sea. It was sheer desire for knowledge that attracted a host of inquirers to investigate the life-history of river-els. The wonder of a fish living in our shallowest pools and travelling two or three thousand miles to breed, very likely on the bottom in 2000 fathoms, and subjected to pressures varying from $14 \mathrm{lb}$. to 2 tons per square inch, is peculiarly attractive. It shows its results in regular eel-farming, the catching and transplantation of the baby eels out of the Severn into suitable waters which cannot, by the efforts of Nature alone, be sure of their regular supply. Purely scientific observations on the life-histories of flat-fish - these were largely stimulated by the scientific curiosity induced by the views of Lamarck and Darwin as to the causes underlying their anatomical development-and on the feeding value and nature of Thisted Bredning and the Dogger Bank, led to the successful experiments on transplantation of young 
plaice to these grounds and the remarkable growthresults obtained, particularly on the latter. Wha can doubt that this "movement of herds" is one of the first results to be applied in the farming of the North Sea so soon as the conservation of our fish supply becomes a question of necessity?

The abundance of mackerel is connected with the movements of Atlantic water into the English Channel and the North Sea-movements depending on complex astronomical, chemical, and physical conditions. They are further related to the food of the mackerel, smaller animal life which dwells only in these Atlantic waters. These depend, as indeed do all animals, on that living matter which possesses chlorophyll for its nutrition, and which we call plant. In this case the plants are spores of algæ, diatoms, etc., and their abundance as food again depends on the amount of the light of the sun-the ultimate source, it might seem, of all life.

A method of ascertaining the age of fishes was sought purely to correlate age with growth in comparison with the growth of air-living vertebrates. This method was found in the rings of growth in the scales, and now the ascertaining of age-groups in herring shoals enables the Norwegian fishermen to know with certainty what possibilities and probabilities are before them in the forthcoming season. From the work on the blending together of Atlantic with Baltic and North Sea water off the Baltic Bight and of the later movements of this "bankwater," as it is termed, into the Swedish fjords can be understood, year by year, the Swedish herring fishery. It is interesting that these fisheries have been further correlated with cycles of sun-spots, and also with longer cycles of lunar changes.

The mass of seemingly unproductive scientific inquiries undertaken by the United States Bureau of Fisheries thirty to fifty years ago was the forerunner of their immense fish-hatching operations, whereby billions of fish-eggs are stripped year by year and the fresh waters of that country made into an important source for the supply of food. The study of the growth-stages of lobsters and crabs has resulted in sane regulations to protect the egg-carrying females, and in some keeping up of the supply in spite of the enormously increased demand. Lastly, the study of free-swimming larval stages in Mollusca, stimulated immensely by their similarity to larval stages in worms and starfishes, has given rise to the establishment of a successful pearl-shell farm at Dongonab, in the Red Sea, and of numerous fresh-water mussel fisheries in the southern rivers of the United States, to supply small shirt-buttons.

Fishery investigation was not originally directed to a more ambitious end than giving a reasonable answer to a question of the wisdom or unwisdom of compulsorily restricting commercial fishing, but it was soon found that this answer could not be obtained without the aid of pure zoology. The spread of trawling-and particularly the introduction of steam trawling during the last century-gave rise to grave fears that the stock of fish in home waters might be very seriously depleted by the use of new methods. We first required to know the life-histories of the various trawled fish, and Sars and others told us that the eggs of the vast majority of the European marine food species were pelagic-in other words, that they floated, and thus could not be destroyed, as had been alleged. Trawl-fishing might have to be regulated all the same, for there might be an insufficient number of parents to keep up the stock. It was clearly necessary to know the habits, movements, and distribution of the fishes, for all were not throughout their life NO. 2654 , VOL. IO6] or at all seasons found on the grounds it was practicable to fish.

But why multiply instances of the applications of zoology as a pure science to human affairs? Great results are asked for on every side of human activities. The zoologist, if he be given a chance to live and to hand on his knowledge and experience to a generation of pupils, can answer many of them. He is increasingly getting done with the collection of anatomical facts, and turning more and more to the why and how animals live. We may not know in our generation or in many generations what life is, but we can know enough to control that life. 'The consideration of the fact that living matter and water are universally associated opens up high possibilities. The experimental reproduction of animals, without the interposition of the male, is immensely interesting; where it will lead no one can foretell. The association of growth with the acidity and alkalinity of the water is a matter of immediate practical importance, especially to fisheries. The probability of dissolved food-material in sea- and river-water, independent of organised organic life and absorbable over the whole surfaces of animals, is clearly before us. Is it possible that that dissolved material may be even now being created in Nature without the assistance of organic life? The knowledge of the existence in food of vitamines, making digestible and usable what in food would otherwise be wasted, may well result in economies of food that will for generations prevent the necessity for the artificial restriction of populations. The parallel between these vitamines and something in sea-water may quite sqon apply practicaily to the consideration of all life in the sea. Finally, what we know of the living matter of germ-cells puts before us the not impossible hope that we may influence for the better the generations yet to come.

So far I have devoted my attention primarily, in this survey of the position of zoology, to the usefulness of the subject. Let us now note where we stand in respect to other subjects and in meeting the real reed for wide zoological study.

Let me give a few facts which have their sweet and bitter for us who make zoology our life-work. During the war we wanted men who had passed the honours schools in zoology-and hence were presumably capable of doing the worls-to train for the diagnosis of protozoal disease. We asked for all names from I905 to I9I4 inclusive, and the average worked out at under fourteen per year from all English universities: an average of one student per university per year. In the year $\mathrm{r}^{\mathrm{I}} \mathrm{I}^{-1} \mathrm{I} 4$ every student who had done his honours course in zoology in I9I3 could, if he had taken entomology as his subject, have been absorbed into the economic applications of that subject. Trained men were wanted to undertake scientific fishery investigations, and they could not be found. Posts were advertised in animal breeding, in helminthology, and in protozoology, three other economic sides of the subject. The Natural History Museum wanted systematists, and there were many advertisements for teachers. How many of these posts were filled I do not know, but it is clear that not more than one-half-or even one-third-can have been filled efficiently. Can any zoologist say that all is well with his subject in the face of these deficiencies?

The demands for men in the economic sides of zoology are continually growing, and it is the business of universities to try to meet these demands. There are Departments of Government at home and in our Colonies which, in the interests of the people they govern, wish to put into operation protective measures, 
but cannot do so because there are not the men with the requisite knowledge and common sense required for inspectorates. There are others that wish for research to develop so as to conserve existing indus. tries as well as to discover new ones, and they, too, are compelled to mark time.

In default, or in spite, of the efforts of the schools of pure zoology, attempts are being made to set up special training schools in fisheries, in entomology, and in other economic applications of zoology. Each branch is regarded as a science, and the supporters of each suppose they can, from the commencement of a lad's scientific training, give specialised instruction in each. 'The researcher in each has to do the research which the economic side requires. But he cannot restrict his education to one science; he requires to know the principles of all sciences; he must attempt to understand what life is. Moreover, his specialist knowledge can seldom be in one science. The economic entomologist, however deep his linowledge of insects may be, will find himself frequently at fault in distinguishing cause and effect unless he has some knowledge of mycologr. The protozoologist must have an intimate knowledge of unicellular plants, bacterial and other. The animal-breeder must know' the work on cross-fertilisation of plants. The fisheries man requires to understand physical oceanography. The helminthologist and the veterinary surgeon require an intimate knowledge of a rather specialised " physiology." All need knowledge of the comparative physiology of animals in other groups beyond those with which they deal, to assist them in their deductions and to aid them to secure the widest outlook. It is surely a mistake, while the greatest scientifi minds of the day find that they require the widest knowledge, to endeavour to set great scientific results out of students whose training has been narsow and specialised. Such specialisation requires to come later, and can replace nothing. This short cut is the longest way round. The danger is not only in our science, but in every science.

Surely the time has now come for us to lift our eyes from our tables of groups and families, and, on the foundations of the knowledge of these, to work on the processes going on in the living body, the adaptation to environment, the problems of heredity, and at many another fascinating hunt in unknown country. Let us teach our students not only what is known, but, still more, what is unknown, for in the pursuit of the latter we shall engage eager spirits who care naught for collections of corpses. My own conviction is that we are in danger of burving our live subject along with our specimens in museums.

As a result of the wrong teaching of zoology, we see proposals to make so-called "Nature-study" in our schools purely botanical. Is this proposal made in the interests of the teacher or of the children? It surely cannot be for "decency" if the teaching is honest, for the phenomena are the same, and there is nothing "indecent" common to all life. "The proper study of mankind is man," and the poor child, athirst for information about himself, is civen a picce of moss or duckweed, or even a chaste buttercup. Is the child supposed to get some knowledge it can apply economically? Whatever the underlying ideas may be, this course will not best develop the mind to enable it to grapple with all phenomena, the aim of education. If necessary, the school teacher must go to school; he must bring himself un to date in his own time, as every teacher in science has to do; it is the business of universities to help him, for nothing is more important to all science than the foundations of knowledge.

No. 2654 , VOL. IO6]

\section{Native Races of the Empire.}

A MONG the resolutions adopted by the General Committee of the British Assuciation during the recent meeting at Cardiff, several dealt with problems connected with the native races of the Empire. Of these one referred to the deplorable conditions now prevailing among the aboriginal tribes of Central Australia, of which an account was recently given in these columns (see Natcre, July 8, g. Gor). The Association urged upon the Federal Government and the Governments of Western Australia and South Australia the desirability of establishing an absolute reservation upon part of the lands now occupied by the tribes within the jurisdiction of these Governments in order that they misht be preserved from extinction. The resolution further emphasised the necessit $\mathrm{w}$ of establishing a medical service for the natives in order to check the ravages of disease by which they are now rapidly being reduced in numbers. It may be hoped that the influence of the Association will add force to the movement which has already been set on foot in South Australia, and induce the Governments concerned to take action in this matter.

$A$ second resolution of the Association dealt with the desirability of initiating an anthropological survey: of the natives of Western Austraila. In this State the natives are under the control of Protectors of Aborigines, and are, for the most part, either located on Government farms or stations, or, if employed by private owners, the conditions of their employment are strictly regulated by the Protectors. Notwithstanding the measures taken for their well-being and preservation, which include a medical service and an or ranised system of food-supply for times of scarcity, they are dwindling in numbers. At the same time, in the changed conditions, the memory of their tribal customs and traditions is beinu lost. In the interests of science it is, therefore, highly desirable that some record should be made of their language, customs, traditions, and beliefs, as well as of their physical characters, before the older members of the tribes die out.

During the past summer, it will be remembered, Gen. Smuts introduced into the South African Parliament a Bill dealing with the native population. This Bill has been described as embodying the most important proposals in reference to the native problem since the Glen Grey Act. Brinfly stated, its main provisions aim at improving the position of the native, and at the same time meeting his claim to a voice in the regulation of his own affairs by develoning a system of local government based unon the tribal social organisation. A further resolution of the Association pointed out that any attempt to bring the native nopulation into closer touch with the social and economic development of the country as a whole - the crucial problem of native legislation in South Africa-could hope to be successful onlv if it were based unon an intimate knowledge of native psrchn. logy and customs, and to this end it ursed unon the Government of the Union the necessitv for the establishment of an Ethnolorical Bureau for the collection of data and the study of native institutions.

\section{Relativity.}

D. C. E. ST. JOHN gives in the Observatory for July some remarks on the search for the Einstein effect in the solar spectrum which was made last year by $\mathrm{L}$. Grebe and A. Bachem at Bonn, and alluded to with anprobation in a letter from Dr. Einstein, quoted in N.ATIRE for January 29 